\title{
A review of Solenysa spiders from Japan (Araneae, Linyphiidae), with a comment on the type species S. mellotteei Simon, 1894
}

\author{
Fang Wang', Hirotsugu $\mathrm{Ono}^{2}$, Lihong Tu'
}

I College of Life Sciences, Capital Normal University, 105, Xisanhuanbeilu Str., Haidian Dist., Beijing, 100048, P. R. China 2 Department of Zoology, National Museum of Nature and Science, 4-1-1, Amakubo, Tsukuba-shi, Ibaraki, 305-0005, Japan

Corresponding author: Lihong Tu (tulh@cnu.edu.cn)

Academic editor: Cor Vink | Received 4 September 2014 | Accepted 15 January 2015 | Published 4 February 2015

http://zoobank.org/OCC2140D-E73F-4DDC-9D49-186CE94CE82A

Citation: Wang F, Ono H, Tu L (2015) A review of Solenysa spiders from Japan (Araneae, Linyphiidae), with a comment on the type species S. mellotteei Simon, 1894. ZooKeys 481: 39-56. doi: 10.3897/zookeys.481.8545

\begin{abstract}
The present paper gives a review of Solenysa species from Japan and provides a solution for the species bearing the generotype name $S$. mellotteei Simon, 1894. A total of six species are recorded, including two new species S. macrodonta sp. n. and S. trunciformis sp. n. The species collected from Kawasaki (NSMT-Ar 11154) and Hachioji should be the generotype $S$. mellotteei, with S. akihisai Tu, 2011, syn. n. as its junior synonym. To distinguish these congeneric species from each other, their genital characters are provided in detail based on images collected by scanning electron microscopy and light microscopy.
\end{abstract}

\section{Keywords}

Genitalia, morphology, new species, taxonomy

\section{Introduction}

The spider genus Solenys $a$ was erected by Simon (1894) to accommodate the linyphiid species, S. mellotteei Simon, 1894, which was collected from Japan by a French diplomat, A. Mellottée. Other Solenysa species were described successively from other places in Japan, the Chinese mainland, Taiwan, and the Korean Peninsula (see review by $\mathrm{Tu}$ and $\mathrm{Li}$ 2006). In recent studies, several new species were sorted from the

Copyright Fang Wang et al. This is an open access article distributed under the terms of the Creative Commons Attribution License (CC BY 4.0), which permits unrestricted use, distribution, and reproduction in any medium, provided the original author and source are credited. 
Solenysa collections deposited in the Department of Zoology, National Museum of Nature and Science (ex National Science Museum, Tokyo), Japan (Tu et al. 2007, Tu and Hormiga 2011, Ono 2011). Prior to this study, there were five Solenysa species reported from Japan: S. mellotteei Simon, 1894 (type locality: Yokohama, Kanagawa Prefecture), S. akihisai Tu, 2011 (type locality: Hachioji, Tokyo), S. ogatai Ono, 2011 (type locality: Okazaki-shi, Aichi Prefecture), S. partibilis Tu, Ono \& Li, 2007 (type locality: Mt. Ibuki-yama, Shiga Prefecture) and S. reflexilis Tu, Ono \& Li, 2007 (type locality: Itsuki-mura, Kumamoto Prefecture). According to results of a phylogenetic analysis based on morphological data, the twelve known Solenysa species were divided into four groups, and the four species from Japan share a complex of genital characters, forming the $S$. mellotteei group (Tu and Hormiga 2011).

As more species were recognized, a problem regarding the type species of Solenysa emerged. Generally, the Solenysa species occurring in Japan are endemic, have a restricted distribution with little overlap (Fig. 7). Small in body size, similar in somatic features and genital morphology, it is difficult to distinguish them from each other without examining their genitalia in detail (Tu and Hormiga 2011). Consequently, all Solenysa spiders collected from the islands of Japan have long been identified as $S$. mellotteei (Oi 1960, Yaginuma 1986, Irie and Saito 1987, Chikuni 1989, Lee et al. 2004, Tu and Li 2006). Redescriptions for the species currently bearing the generotype name, S. mellotteei, in reviews of Solenysa were not based on the type material ( Tu and Li 2006, Tu and Hormiga 2011) and the species are different from those collected from the places more adjacent to the inferred type locality (Ono 2011). It is necessary to make a review to distinguish the species of the $S$. mellotteei group and to establish the identity of the generotype $S$. mellotteei. From the materials collected throughout the islands of Japan, we identified six species in total, including two new species and one new synonymy. In the present study, all these Solenysa spiders were studied by using scanning electric microscopy (SEM) and light microscopy to show genital characters in detail. Descriptions for the new species and redescriptions for the known species are presented.

\section{Materials and methods}

Specimens were examined and measured by using a Leica MZ16A stereo microscope. Further details, such as epigynes, were studied with a Leica DM5500B compound microscope. Digital images were taken with a Leica DFC 500 camera and as a composite of multiple focus images assembled using the software package Leica Application Suite. Epigynes were cleared in methyl salicylate (Holm 1979) for examination under the microscope and temporarily mounted as described by Grandjean (1949) and Coddington (1983). SEM images were taken by using a Hitachi S-3400N scanning electron microscope at China Agriculture University. For SEM examination, the 
specimens were prepared as described by Álvarez-Padilla and Hormiga (2008). The non-chitinous abdominal tissue was digested with Sigma Pancreatin LP 1750 enzyme complex to expose the internal structures for examination. Due to the unavailability of specimen, no SEM image provided for the male palp of S. reflexlis.

All measurements are given in millimeters. The leg measurements are given in the following sequence: Total (femur, patella+tibia, metatarsus, tarsus). Terminology for the genital characters follows Tu and Hormiga (2011). The specimens examined here have been deposited in the Department of Zoology, National Science Museum, Tokyo, Japan (NSMT) and in College of Life Sciences, Capital Normal University, Beijing (China).

\section{Anatomical abbreviations used in the text and figures}

\section{Male palp}

$\begin{array}{ll}\text { ATA } & \text { anterior terminal apophysis } \\ \text { DSA } & \text { distal suprategular apophysis } \\ \text { E } & \text { embolus } \\ \text { LC } & \text { lamella characteristica } \\ \text { LC }_{1} & \text { anterior branch of LC } \\ \text { LC }_{2} & \text { median branch of LC } \\ \text { LC } & \text { posterior branch of LC } \\ \text { MTA } & \text { median terminal apophysis } \\ \text { P } & \text { paracymbium } \\ \text { PBP } & \text { cymbial probasal process } \\ \text { PTA } & \text { posterior terminal apophysis } \\ \text { R } & \text { radix } \\ \text { STT } & \text { solenysa tegular triangle } \\ \text { T } & \text { tegulum }\end{array}$

\section{Epigyne}

$\begin{array}{ll}\text { CG } & \text { copulatory groove } \\ \text { CO } & \text { copulatory opening } \\ \text { DP } & \text { dorsal plate } \\ \text { EC } & \text { epigynal collar } \\ \text { FG } & \text { fertilization groove } \\ \text { S } & \text { spermatheca } \\ \text { SL } & \text { solenoid } \\ \text { VP } & \text { ventral plate }\end{array}$




\section{Taxonomy}

\section{Linyphiidae Blackwall, 1859}

\section{Solenysa Simon, 1894}

Type species. Solenysa mellotteei Simon, 1894.

Composition. Fourteen species including two new species: Solenysa geumoensis Seo, 1996, S. lanyuensis Tu, 2011, S. longqiensis Li \& Song, 1992, S. macrodonta sp. n., S. mellotteei Simon, 1894, S. ogatai Ono, 2011, S. partibilis Tu, Ono \& Li, 2007, S. protrudens Gao, Zhu \& Sha, 1993, S. reflexilis Tu, Ono \& Li, 2007, S. retractilis Tu, 2011, S. tianmushana Tu, 2011, S. trunciformis sp. n., S. wulingensis Li \& Song, 1992 and S. yangmingshana $\mathrm{Tu}, 2011$.

Diagnosis. Solenysa species can be distinguished from all other linyphiids by the four lobes at the sides of carapace, the rounded pits scattered on the carapace and the tubular-shaped petiole (Fig. 1A-B). Females are also diagnosed by the presence of a long membranous solenoid, connecting between the epigyne and the abdomen (Fig. 1D), males by the presence of Solenysa tegular triangle in male palp (Fig. 2A).

Description. See Tu and Li (2006) and Tu and Hormiga (2011).

Distribution. Japan, Chinese mainland, Taiwan, Korea.

Comments. The subfamily placement of Solenysa remains controversial as its complex type of male palp with well developed lamella characteristica and terminal apophysis is like those in Micronetinae Hull, 1920, but the simple type of epigyne is like those in Erigoninae Emerton, 1882. Based on the movable epigyne, Saaristo (2007) included it in his new subfamily Ipainae Saaristo, 2007. However, the results of a phylogenetic analysis of Linyphiidae queried the monophyly of "ipaines", and suggested that "micronetines" and erigonines form a monophyletic group (Arnedo et al. 2009). Furthermore, the results of a phylogenetic analysis of erigonines based on morphological data showed that all Solenysa species form a monophyly robustly supported by a long list of synapomorphies, and other synapomorphies suggested its close relationship with erigonines although its sister group remained unresolved (Tu and Hormiga 2011). Accordingly, the well-developed lamella characteristica and terminal apophysis in Solenysa should be regarded as homologous to those of "micronetines" and secondarily lost in erigonines; their simple type epigyne also derived from the complex type of "micronetines". The morphology of solenoid in Solenysa is different from the extensive basal parts in Acanoides beijingensis Sun, Marusik \& Tu, 2014 and A. hengshanensis (Chen \& Yin, 2000) (Sun et al. 2014: figs 4G, 5G), and in Wubanoides uralensis (Pakhorukov, 1981), Epibellowia enormita (Tanasevitch, 1988) and E. septentrionalis (Oi, 1960) (Tanasevitch 1996: figs 7-9). Whether the movable epigyne has a single origin or independently evolved multiple times in linyphiids needs to be tested in future studies.

A phylogenetic analysis based on morphological data (Tu and Hormiga 2011) suggested that the twelve known Solenysa species are divided into four clades. Among 

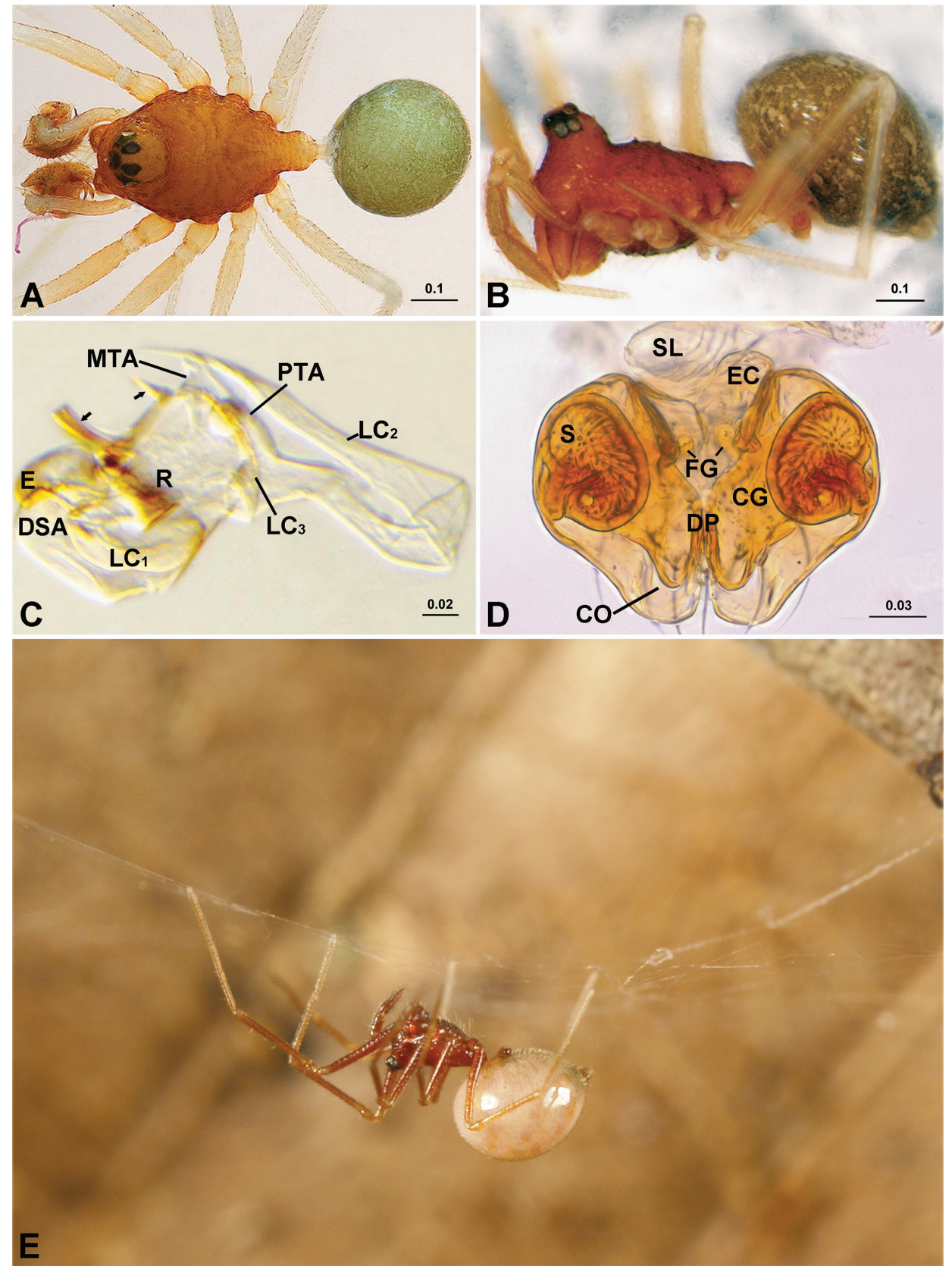

Figure I. Solenysa trunciformis sp. n. (A-D) and S. partibilis (E). A male, dorsal B female, lateral C male palpal embolic division, ventral, arrows indicate two anterior protrusions of MTA D epigyne, dorsal $\mathbf{E}$ female, lateral in living state, showing non-functional state of epigyne. $\mathbf{C O}$ copulatory opening; CG copulatory groove; DP dorsal plate; DSA distal suprategular apophysis; $\mathbf{E}$ embolus; EC epigynal collar; FG fertilization groove; $\mathbf{L C}$ lamella characteristica; $\mathbf{L C}_{1}$ anterior $\mathrm{LC}$ branch; $\mathbf{L C}_{2}$ median $\mathrm{LC}$ branch; $\mathbf{L C}_{\mathbf{3}}$ posterior LC branch; MTA median terminal apophysis; PTA posterior terminal apophysis; $\mathbf{R}$ radix; $\mathbf{S}$ spermatheca; $\mathbf{S L}$ solenoid. Photo of $S$. partibilis provided by Akihisa Andoh. [Scale bars: $\mathrm{mm}$ ] 
them, the four species occurring in Japan formed a monophyletic clade, unambiguously supported by the following synapomorphies: the presences of hook shaped cymbial probasal process, half rounded Solenysa tegular triangle and copulatory grooves enter the spermathecae from the outer sides.

\section{Solenysa mellotteei group Tu \& Hormiga, 2011}

Composition. Six species: Solenysa mellotteei Simon, 1894, S. macrodonta sp. n., S. ogatai Ono, 2011, S. partibilis Tu, Ono \& Li, 2007, S. reflexilis Tu, Ono \& Li, 2007 and S. trunciformis sp. n.

Diagnosis. Males of $S$. mellotteei group are distinguished from all other three groups by the spiral plate-shaped embolus (Fig. 3E), the hook-shaped cymbial probasal process and by the half rounded Solenysa tegular triangle (Fig. 2A). Females are characterized by the dorsoventrally folded solenoid (Figs 4C, 5C), the spherical spermathecae and the pocket shaped copulatory grooves entering the spermathecae from the outer sides (Fig. 1D).

Description. All Solenysa species have quite uniform somatic morphology. Somatic characters as in the genus description (see also Tu and Li 2006, Tu and Hormiga 2011).

Male palp (Fig. 2A-B). Tibia twice as long as patella, with proximal process furnished by two long bristles. Cymbium with hook-like proximal process and small retrolateral process, forming articulation with proximal arm of U-shaped paracymbium. Tegulum with half rounded Solenysa tegular triangle and stout distal suprategular apophysis. Embolic division (Fig. 6): embolus spiral plate shaped with two apophyses, one at outer margin, and one distally (Fig. 3E). Radix embedded within membranous area connecting terminal apophysis and lamella characteristica (Figs 1C, 2B). Terminal apophysis divided into three parts, with median one as enlarged sclerite. Lamella characteristica with three well-developed branches, anterior branch $\left(\mathrm{LC}_{1}\right.$ ) stout and extending forward, following embolus trajectory; median one $\left(\mathrm{LC}_{2}\right)$ long and slender, dragging backwards and pointing forward, bifid in some species (Fig. $3 \mathrm{~A}$ ); posterior one ( $\mathrm{LC}_{3}$ ) sharp and strongly sclerotized, bifid in some species (Fig. 3B).

Epigyne (Figs 1D, 4A-B). Strongly sclerotized box-shaped, having a well-developed epigynal collar at anterior part connecting with solenoid. Solenoid flexible, dorsoventrally folded (Fig. 5C) in non-functional stage, holding epigyne up (Fig. 1E). Spermathecae large spherical. Copulatory openings as a pair of crescent shaped slits hidden on dorsal surface. Copulatory grooves enlarged into half round pocket-shaped, matching to spiral plate-shaped embolus, entering spermathecae outboard. Fertilization grooves convergent, extending forward.

Distribution. Japan (Honshu, Shikoku, Kyushu, Fig. 7). 


\section{Solenysa mellotteei Simon, 1894}

Figs 2, 4A-B, 6A

S. mellottei Simon, 1894: 677; Lee et al. 2004: 100; Ono et al. 2009: 330, figs 1087-1091. S. mellotteei: Yaginuma 1986: 78, fig. 42.2; Irie and Saito 1987: 23, fig. 21; Chikuni 1989: 56, fig. 48.

S. akihisai: Tu and Hormiga 2011: 499, fig. 8A-I.

Material examined. $1 \delta^{\Uparrow}$ and 19 (NSMT-Ar 11154), Japan, Honshu, Kanagawa Prefecture, Kawasaki-shi, Asao-ku, Kurokawa, 3532'N, 13943'E, 15 Nov. 1997, coll. Mitsuru Ban; $10^{\hat{\gamma}}$ and 2 우, Japan, Honshu, Tokyo, Hachioji, 35 $42^{\prime} \mathrm{N}, 139^{\circ} 18^{\prime} \mathrm{E}$, 20 Dec. 2003, coll. Akihisa Andoh; $3 \hat{\jmath} \widehat{o}^{\lambda}$ and 3 우 (CNU-J02), Japan, Honshu, Ibaraki Prefecture, Mito-shi, Tara, $36^{\circ} 24.35^{\prime} \mathrm{N}, 140^{\circ} 24.55^{\prime} \mathrm{E}, 27$ Nov. 2000, coll. Akihisa Andoh; $3 \hat{\jmath} \widehat{\jmath}$ and 7 우, Japan, Honshu, Tokyo, Hachioji, Kamikawa, $35^{\circ} 42.55^{\prime} \mathrm{N}$,

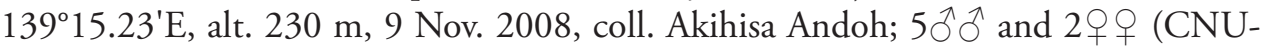
J22), Japan, Honshu, Kanagawa Prefecture, Miura, Ko-ajiro, 3509.88'N, $139^{\circ} 37.65^{\prime}$ E,

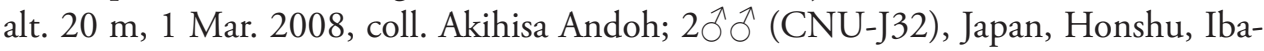
raki Prefecture, Mito, Tano, 36 $24.55^{\prime} \mathrm{N}, 140^{\circ} 24.38^{\prime} \mathrm{E}$, alt. $45 \mathrm{~m}, 13$ Jun. 2009, coll. Akihisa Andoh.

Diagnosis. Solenysa mellotteei is similar to $S$. partibilis and S. ogatai in male palps having the posterior branch of lamella characteristica $\left(\mathrm{LC}_{3}\right)$ divided into two parts (Fig. 6A, C, D), and in females having an apple-shaped epigyne. Males can be distinguished by: the anterior part of $\mathrm{LC}_{3}$ is flag-shaped in S. mellotteei (Fig. 2B), long spike-shaped in S. ogatai (Fig. 3C) and S. partibilis (Fig. 3D); the posterior part of $\mathrm{LC}_{3}$ S-curved in S. ogatai (Fig. 3C), L-curved in S. partibilis (Fig. 3D). Females can be distinguished by the inverse triangular epigynal collar and the dorsal plate as wide as long in S. mellotteei (Fig. 4A, Tu and Hormiga 2011: fig. 8I), the dorsal plate wider than long in S. partibilis and S. ogatai (Fig. 5B, D), and the epigynal collar more than four times wider than long in $S$. ogatai (Fig. 5B), less than twice wider than long in $S$. partibilis (Tu and Hormiga 2011: fig. 11I).

Description. S. mellotteei has somatic morphology typical of Solenysa (Fig. 1A, B, E) and a genital pattern of the S. mellotteei group (Fig. 2A-B). For somatic and genital characters, see the description provided by Tu and Hormiga (2011) for S. akihisai, the junior synonym of $S$. mellotteei.

Distribution. Japan (Honshu, Fig. 7).

Comments. The problem with the identification of the generotype Solenysa mellotteei arose because Solenysa species occurring in Japan, previously all identified as S. mellotteei, are now distinguished as six species. Since most of them have restricted distributions without any overlap (Fig. 7), it has long remained ambiguous which species is the original $S$. mellotteei described by Simon (1894). The type material of $S$. mellotteei was not located ( $\mathrm{Tu}$ and $\mathrm{Li}$ 2006), and the original description by Simon (1894) did not provide detailed information about the type locality. According to Ono 


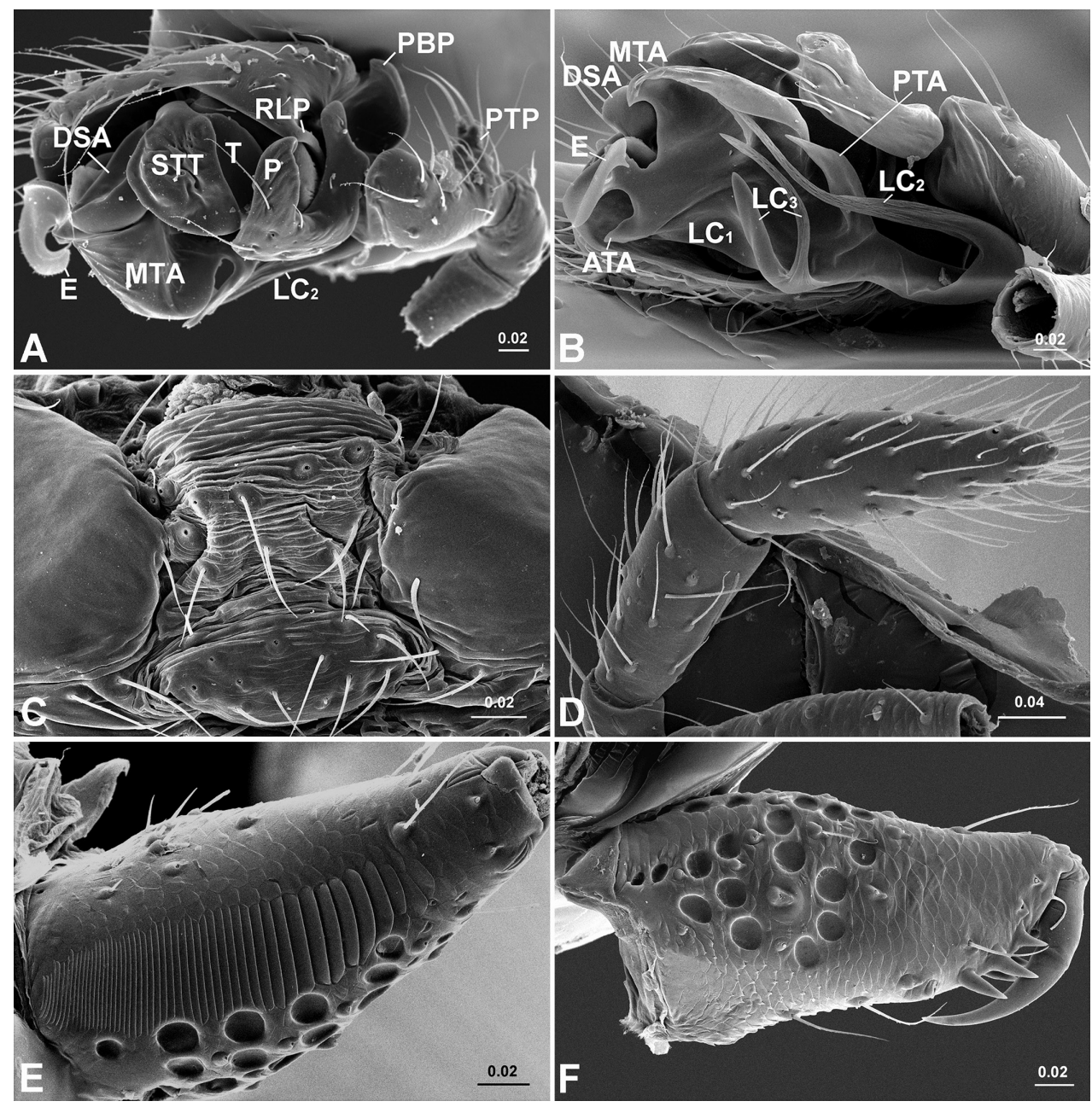

Figure 2. Solenysa mellotteei. A male palp, retrolateral B ditto, ventral $\mathbf{C}$ anterior part of male abdomen, ventral, shows epiandrous fusules absent and smooth book lung cover $\mathbf{D}$ female palp, shows tarsus claw absent $\mathbf{E}$ male chelicera, ectal, shows stridulatory striae $\mathbf{F}$ female chelicerae. ATA anterior terminal apophysis; DSA distal suprategular apophysis; E embolus; LC lamella characteristica; $\mathbf{L C}_{\mathbf{1}}$ anterior LC branch; $\mathbf{L C}_{2}$ median LC branch; $\mathbf{L C}_{3}$ posterior LC branch; MTA median terminal apophysis; $\mathbf{P}$ paracymbium; PBP probasal cymbial process; PTA posterior terminal apophysis; PTP proximal tibial process; RLP cymbial retrolateral process; STT Solenysa tegular triangle; $\mathbf{T}$ tegulum. [Scale bars: $\mathrm{mm}$ ]

(2011), the French diplomat A. Mellottée, who had spent only two years in Japan, stayed in the foreign settlement at Yokohama and collected spiders in the surrounding area. All his collections were contributed to the National Museum of Natural History, Paris (Ono 1987, Takahashi 2000) and studied by Simon (1886a, 1886b, 1889, 1893, 1894, 1895). For that reason, Ono (2011) inferred the type locality of S. mellotteei should be Yokohama, Kanagawa Prefecture. In the first review of the genus by Tu and 


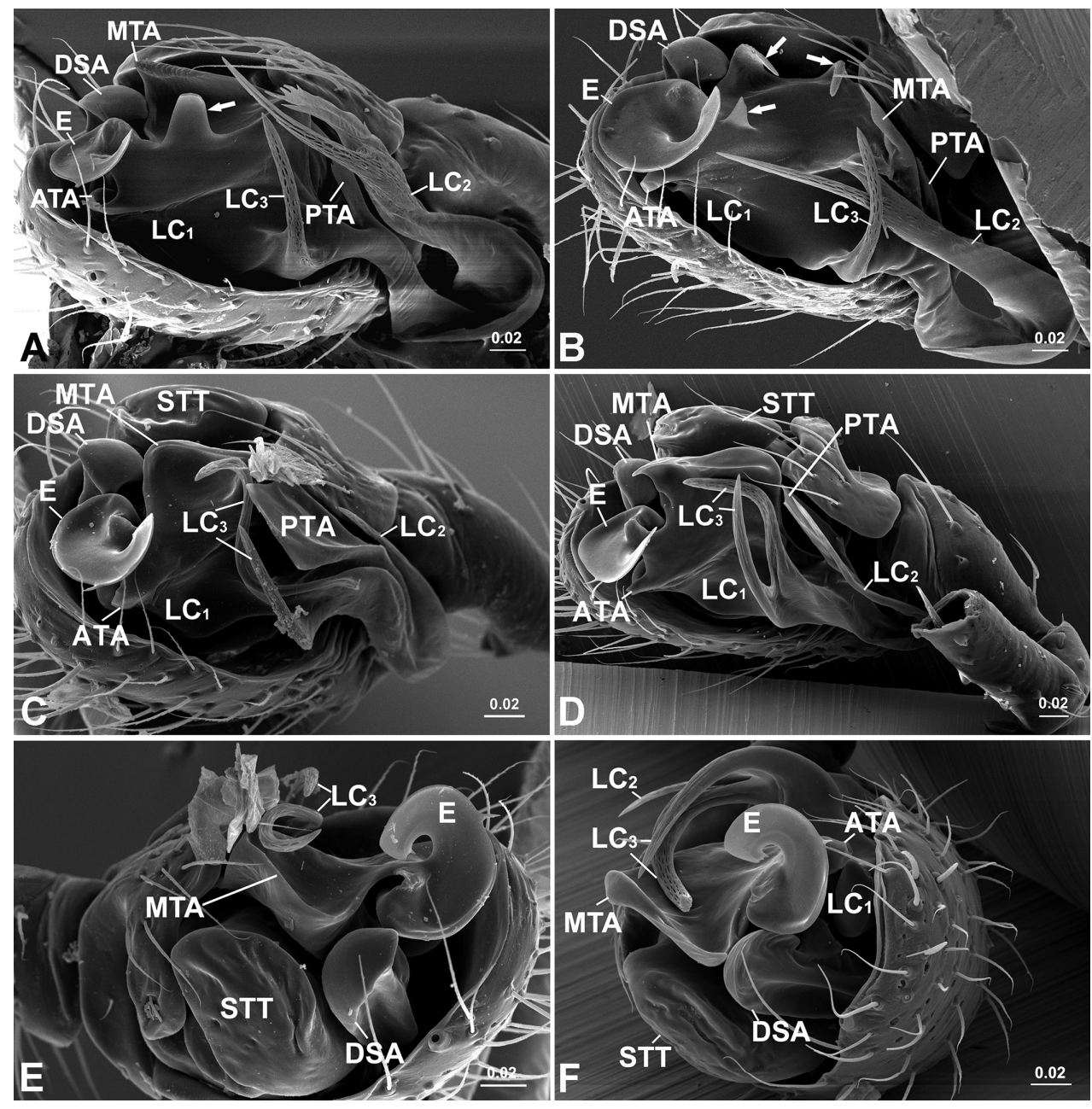

Figure 3. Male palpal embolic division. A Solenysa macrodonta sp. n., ventral, arrow indicates central tooth B S. trunciformis sp. n., ventral, arrows indicate central tooth and two anterior protrusions of MTA C $S$. ogatai, ventral D $S$. partibilis, ventral E S. ogatai, anterior F S. partibilis, anterior. ATA anterior terminal apophysis; DSA distal suprategular apophysis; $\mathbf{E}$ embolus; $\mathbf{L C}$ lamella characteristica; $\mathbf{L C}_{1}$ anterior LC branch; $\mathbf{L C}_{2}$ median LC branch; $\mathbf{L C}_{3}$ posterior LC branch; MTA median terminal apophysis; PTA posterior terminal apophysis; STT Solenysa tegular triangle. [Scale bars: $\mathrm{mm}$ ]

$\mathrm{Li}$ (2006), the redescription of $S$. mellotteei was based on a pair of specimens sent by a Japanese scholar and did not include any collecting data. In the phylogenetic revision of Solenysa (Tu and Hormiga 2011), the supplementary material of the same species did not come from the type locality, but from Esuzaki, Susami-cho, Wakayama Prefecture. However, specimens collected from Hachioji, Tokyo, which is much closer to the type locality (Fig. 7), were proposed as a new species S. akihisai. In the present study we examined material collected from three localities adjacent to Yokohama: Hachioji, 
Kawasaki (NSMT-Ar 11154) and Miura (Fig. 7), as well as specimens from Mito, and found that they are the same species, which should bear the generotype name $S$. mellotteei, and S. akihisai is a junior synonym of it. The materials collected from Wakayama Prefecture, and those from Shikoku Island are proposed here as a new species S. trunciformis sp. n.

\section{Solenysa macrodonta sp. $\mathbf{n}$.}

http://zoobank.org/E937495C-A852-4FB6-8739-F40F5AA5C1E8 Figs 3A, 4C-D

Types. Male holotype (CNU-J21), Japan, Honshu, Shimane Prefecture, Yunotsu, Nishida, $35^{\circ} 05.06$ 'N, $132^{\circ} 24.10^{\prime}$ E, 27 Jul. 2006, coll. Akihisa Andoh. Paratype, 1 , same data as holotype.

Diagnosis. The male palp of Solenysa macrodonta sp. n. is similar to those of $S$. trunciformis sp. n. and S. refrexilis in the presence of a central tooth at the membranous area embedded the radix (Figs 1C, 3A, 6B), the forked apex of the median branch of lamella characteristica and the long spike-shaped posterior branch (Fig. 3A-B). They can be distinguished from each other by the median part of terminal apophysis, which has a serrate margin in $S$. macrodonta sp. n. (Fig. 3A), but with two anterior protrusions in S. trunciformis sp. n. (Fig. 3B) and S. refrexilis (Tu et al. 2007: fig. 1D), which is truncate in the former species and pointed in the latter species. The short epigyne of S. macrodonta sp. n. is similar to those of S. partibilis and S. reflexilis, having the dorsal plate wider than long (Fig. 5D). They can be distinguished from each other by the maximum width in ventral view; at the anterior part in S. partibilis (Fig. 5C), in the middle in S. macrodonta sp. n. (Fig. 4C), and posterior in S. reflexilis (Fig. 4E), which also has a straight posterior margin.

Description. Male holotype. Total length 1.33. Carapace, 0.8 long, 0.48 wide. Abdomen, 0.53 long, 0.38 wide. Chelicera with four promarginal and two retromarginal teeth. Length of legs: I $2.53(0.68+0.80+0.58+0.47)$; II $2.25(0.60+0.66$ $+0.50+0.49)$; III $1.69(0.47+0.50+0.39+0.33)$; IV $1.98(0.61+0.64+0.43+$ $0.30)$. Tm I: 0.23 , Tm IV absent. Measurements for the female were not possible since the single specimen was prepared for SEM examination. Other somatic characters are as in the genus description (Fig. 1A, B, E; see also Tu and Li 2006, Tu and Hormiga 2011).

Male palp (Fig. 3B). General male palpal characters are as in the description for the S. mellotteei group. Embolic division (Fig. 6B): radix embedded in the central membranous area connecting with terminal apophysis and lamella characteristica, from where a central tooth protrudes. Median part of terminal apophysis as large sclerite with serrated margin. Anterior branch of lamella characteristica reduced, stout and extending forward following embolus; the median branch ribbon-like, 


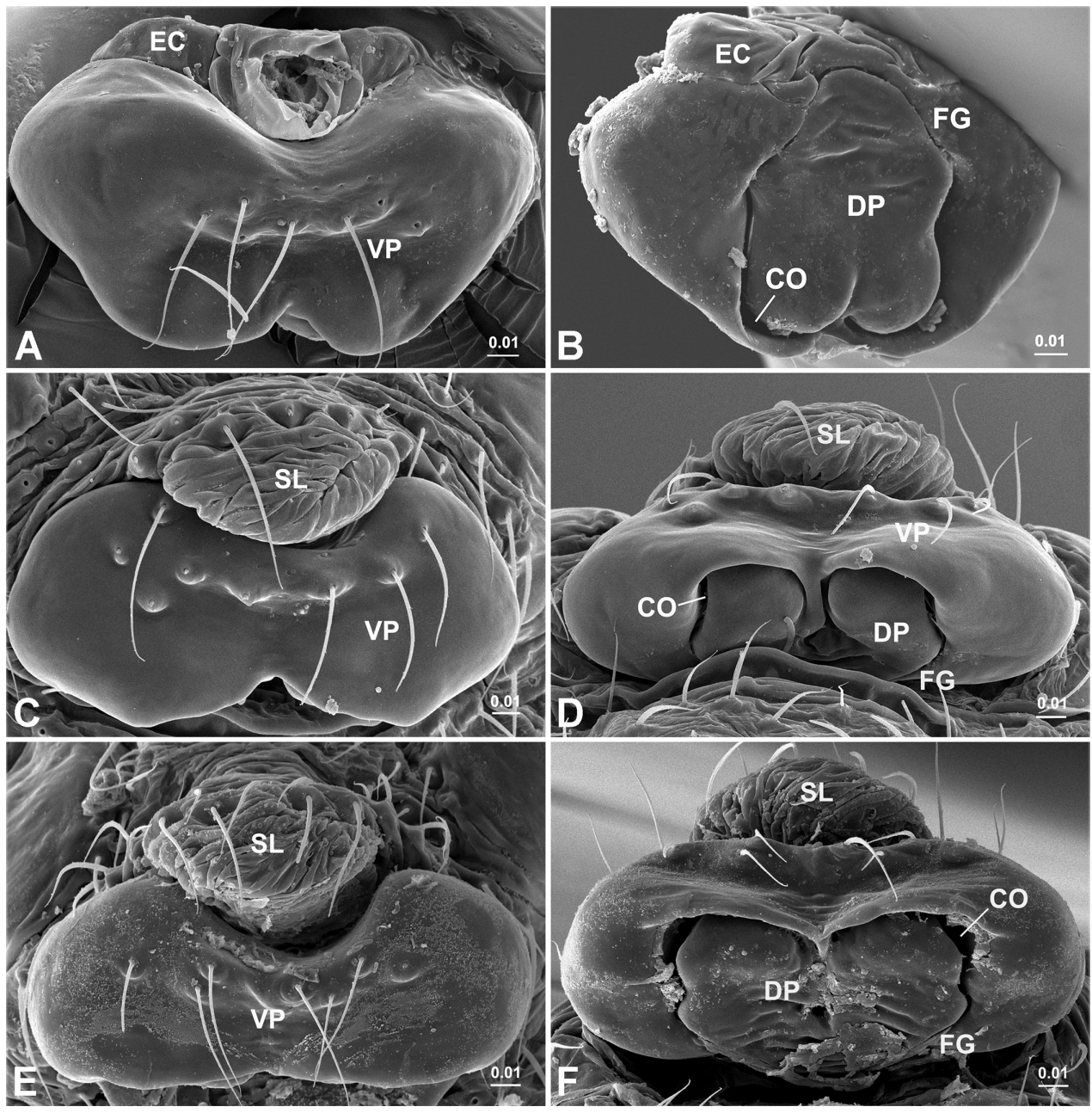

Figure 4. Epigyne. Solenysa mellotteei (A-B), S. macrodonta sp. n. (C-D), S. reflexilis (E-F). A, C, E ventral, A with epigynal collar removed $\mathbf{B}, \mathbf{D}, \mathbf{F}$ dorsal. CO copulatory opening; DP dorsal plate; EC epigynal collar; FG fertilization groove; VP ventral plate; $\mathbf{S L}$ solenoid. [Scale bars: $\mathrm{mm}$ ]

long and slender, dragging backwards, then folding forward, with forked apex, one sharp, one with threaded margin; the posterior long spike-shaped and strongly sclerotized.

Epigyne (Fig. 4C-D). Twice as wide as long in ventral view, with maximum width in the middle. Posterior margin centrally incised. Dorsal plate wider than long.

Etymology. The species name is based on the Latin 'macrodontus' in reference to the large central tooth protruding from the membranous area connecting with terminal apophysis and lamella characteristica (Fig. 3A).

Distribution. Japan (Honshu, Fig. 7). 


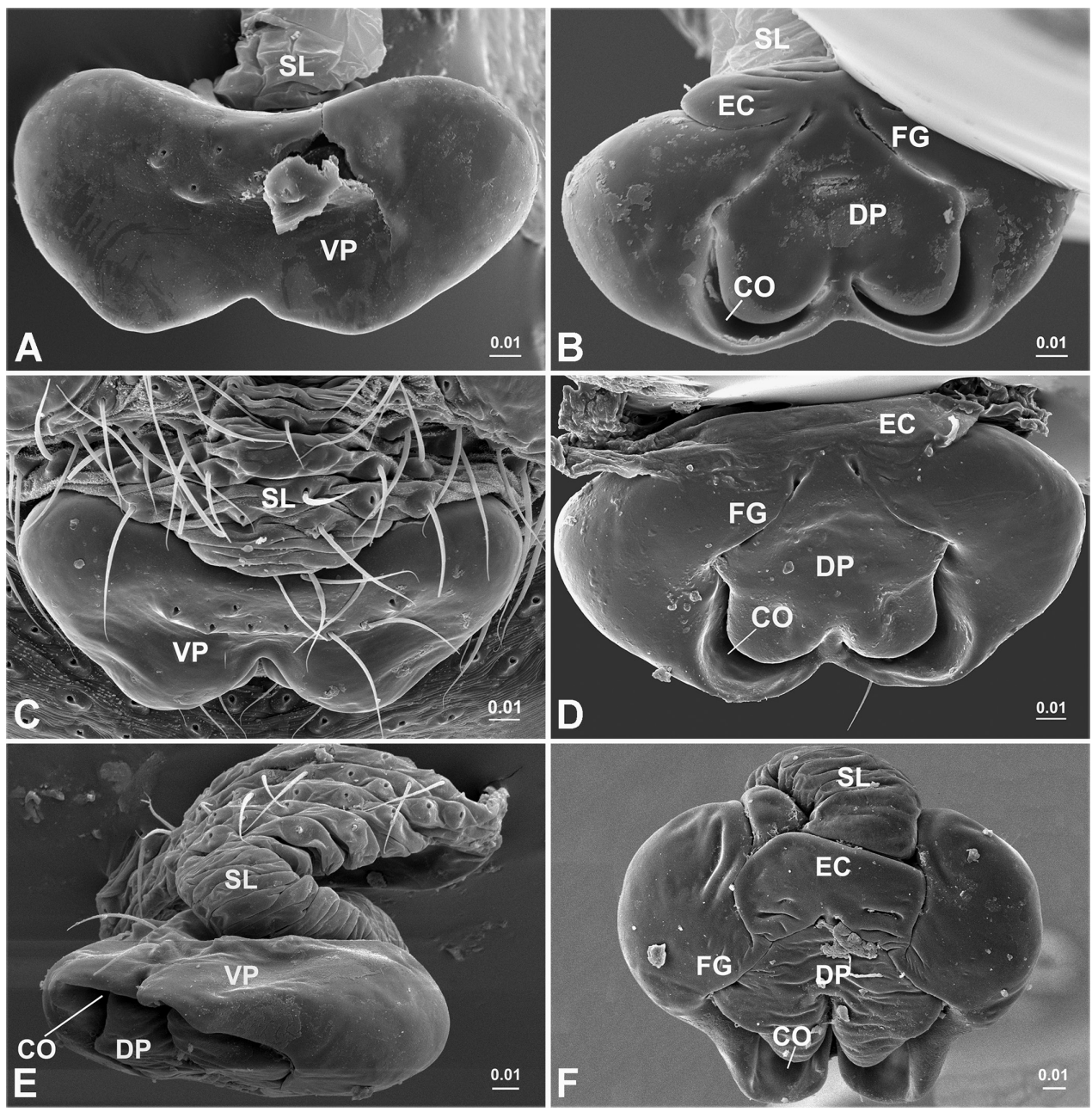

Figure 5. Epigyne. Solenysa ogatai (A-B), S. partibilis (C-D), S. trunciformis sp. n. (E-F). A, C ventral $\mathbf{B}, \mathbf{D}, \mathbf{F}$, dorsal $\mathbf{E}$ lateral, with solenoid artificially loosened. CO copulatory opening; DP dorsal plate; EC epigynal collar; FG fertilization groove; VP ventral plate; SL solenoid. [Scale bars: $\mathrm{mm}$ ]

\section{Solenysa ogatai Ono, 2011}

Figs 3C, E, 5A-B

Solenysa ogatai Ono, 2011: 126, figs 11-17.

Types. Male holotype (NSMT-Ar 9741), Japan, Honshu, Aichi Prefecture, Okazakishi, Okuyamada-cho, Mt. Murazumi-yama, alt. 200-250 m, 5 May 2011, coll. Ki-

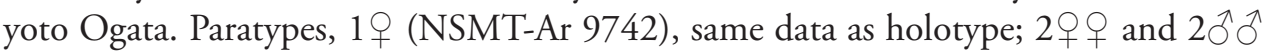
(NSMT-Ar 9743), same data as holotype. 

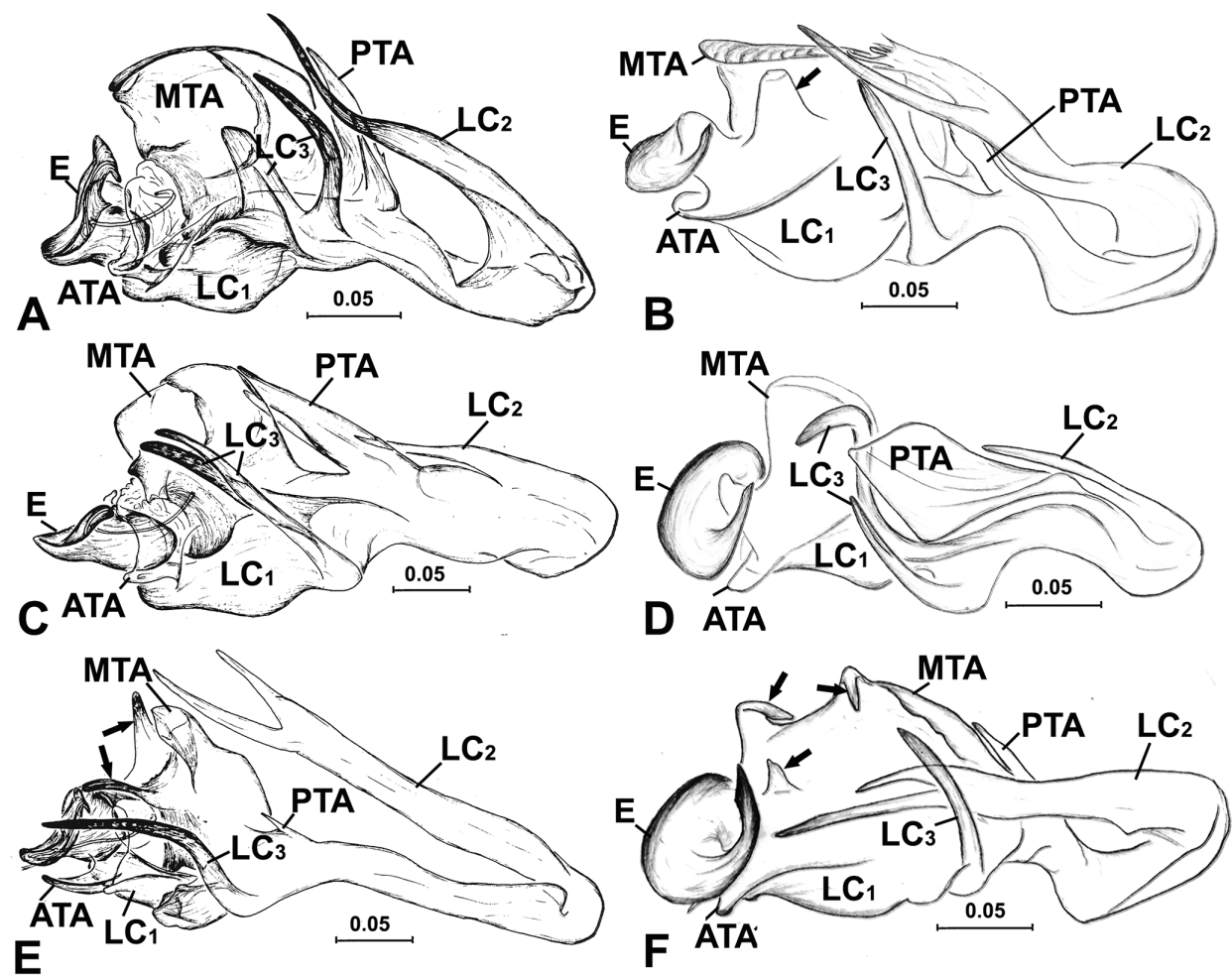

Figure 6. Male palpal embolic division, ventral. A Solenysa mellotteei B $S$. macrodonta sp. n., arrows
indicate central tooth C S. partibilis D . ogatai E S. reflexilis, arrows indicate two anterior protrusions
F S. trunciformis sp. n., arrows indicate central tooth and two anterior protrusions of MTA. ATA anterior
terminal apophysis; E embolus; LC lamella characteristica; LC $_{1}$ anterior LC branch; LC $_{2}$ median LC
branch; LC ${ }_{3}$ posterior LC branch; MTA median terminal apophysis; PTA posterior terminal apophysis;
STT Solenysa tegular triangle. [Scale bars: $\mathrm{mm}$ ]

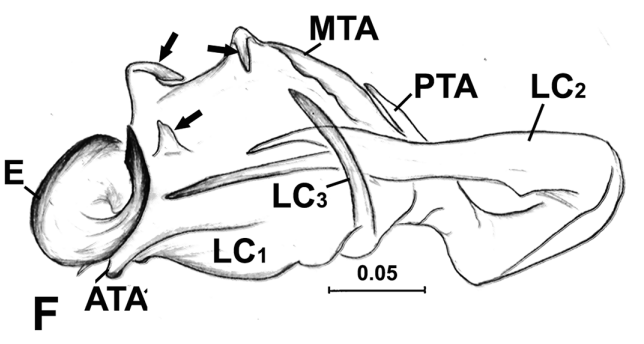

Diagnosis. The genital characters of $S$. ogatai are very similar to those of $S$. partibilis (Figs 3C-F, 6C-D). The male palp is diagnosed by the posterior branch of the lamella characteristica with two long free ends, the longer one in $S$. ogatai is sigmoid curved in ventral view (Fig. 3C), almost a circle in anterior view (Fig. 3E), while in S. partibilis L-curved in ventral view (Fig. 3D), half circle in anterior view (Fig. 3F). The epigyne can be distinguished by the epigynal collar, which is more than four times wider than long in S. ogatai (Fig. 5B), but less than twice as wide than long in S. partibilis (Tu and Hormiga 2011: fig. 11I).

Description. Somatic characters as in the genus description and for genital characters see Ono (2011).

Distribution. Japan (Honshu, Fig. 7). 


\section{Solenysa partibilis Tu, Ono \& Li, 2007}

Figs 1E, 3D, F, 5C-D

S. melloteei: Oi 1960: 153, figs 52-54 (misidentification).

Solenysa partibilis Tu, Ono \& Li, 2007: 60, fig. 2A-D; Ono et al. 2009: 332, figs 1092-099; Tu and Hormiga 2011: figs 11I, 12A-H, 13A-H.

Type. Male holotype (NSMT-Ar 2776), Japan, Honshu, Shiga Prefecture, Mt. Ibuki, $35^{\circ} 12^{\prime} \mathrm{N}, 136^{\circ} 12^{\prime} \mathrm{E}, 11$ Nov. 1957, coll. Ryoji Oi.

Additional Material examined. $3 \delta^{\lambda}$ and $3 q q$, Japan, Honshu, Tokyo, Omeshi, Mitake, $35^{\circ} 48^{\prime} \mathrm{N}, \mathrm{E} 139^{\circ} 10.80^{\prime} \mathrm{E}, 17$ Oct. 2004, coll. Akihisa Andoh;

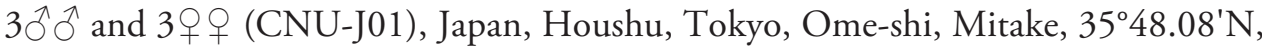
E139 ${ }^{\circ} 11.15^{\prime} \mathrm{E}, 17$ Oct. 2004, coll. Akihisa Andoh; 3 우 (CNU-J25), Japan, Honshu, Fukushima Prefecture, Fukushima-shi, Kanayagawa, $37^{\circ} 41.42^{\prime} \mathrm{N}, 140^{\circ} 27.18^{\prime} \mathrm{E}$, alt.

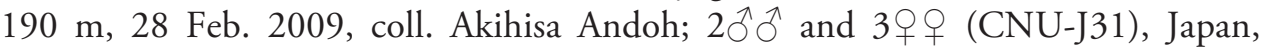
Honshu, Shiga Prefecture, Maibara (base of Mt. Ibuki), Ohshimizu, $35^{\circ} 22.37^{\prime} \mathrm{N}$, 136 24.08'E, alt. 190 m, 2 Jun. 2009, coll. Akihisa Andoh; 19 (CNU-J33), Japan, Honshu, Niigata Prefecture, Niitsu, Akihayama, $37^{\circ} 47.02^{\prime} \mathrm{N}, 139^{\circ} 08.32^{\prime} \mathrm{E}$, alt. 50 m, 20 Jun. 2009, coll. Akihisa Andoh; 1 + (CNU-J34), Japan, Honshu, Niigata Prefecture, Niitsu, $37^{\circ} 46^{\prime} \mathrm{N}, 139^{\circ} 08.20^{\prime} \mathrm{E}$, alt. $50 \mathrm{~m}$, 20 Jun. 2009, coll. Akihisa Andoh; 2 우 (CNU-J35), Japan, Honshu, Akita Prefecture, Akita-shi, Katsurane,

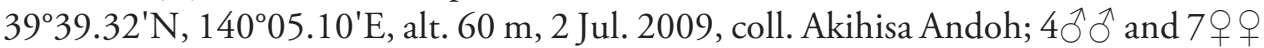
(CNU-J36), Japan, Honshu, Miyagi Prefecture, Sendai, Mt.Takamori, 38 $19.03^{\prime} \mathrm{N}$,

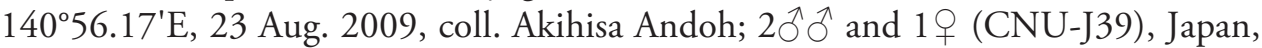
Honshu, Tokyo, Ome, Yugi, 3548.18'N, 139¹1.98'E, alt. 240 m, 12 Sept. 2009, coll. Akihisa Andoh.

Diagnosis. See diagnosis for $S$. ogatai.

Description. Somatic characters as in the genus description (Fig. 1E, see also $\mathrm{Tu}$ and Li 2006, Tu and Hormiga 2011), and genital characters see the descriptions by $\mathrm{Tu}$ et al. (2007) and Tu and Hormiga (2011).

Distribution. Japan (Honshu, Fig. 7).

\section{Solenysa reflexilis $\mathrm{Tu}$, Ono \& Li, 2007}

Fig. 4E-F

Solenysa reflexilis Tu, Ono \& Li, 2007: 58, fig. 1A-H; Ono et al. 2009: 332, figs 1100-1104.

Types. Male holotype (NSMT-Ar 3905), Japan, Kyushu, Kumamato Prefecture, Kumagun, Itsukimura, Shimo-kajiwara, $32^{\circ} 12^{\prime} \mathrm{N}, 130^{\circ} 30^{\prime} \mathrm{E}, 27$ Oct. 1981, coll. Teruo Irie.

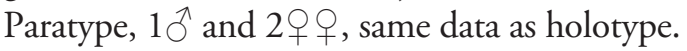

Additional material examined. 2 우 (CNU-J28), Japan, Kyushu, Kumamoto Prefecture, Itsuki, Touji, 32²3.63'N, 13049.67'E, alt. 310 m, 27 Apr. 2009, coll. 


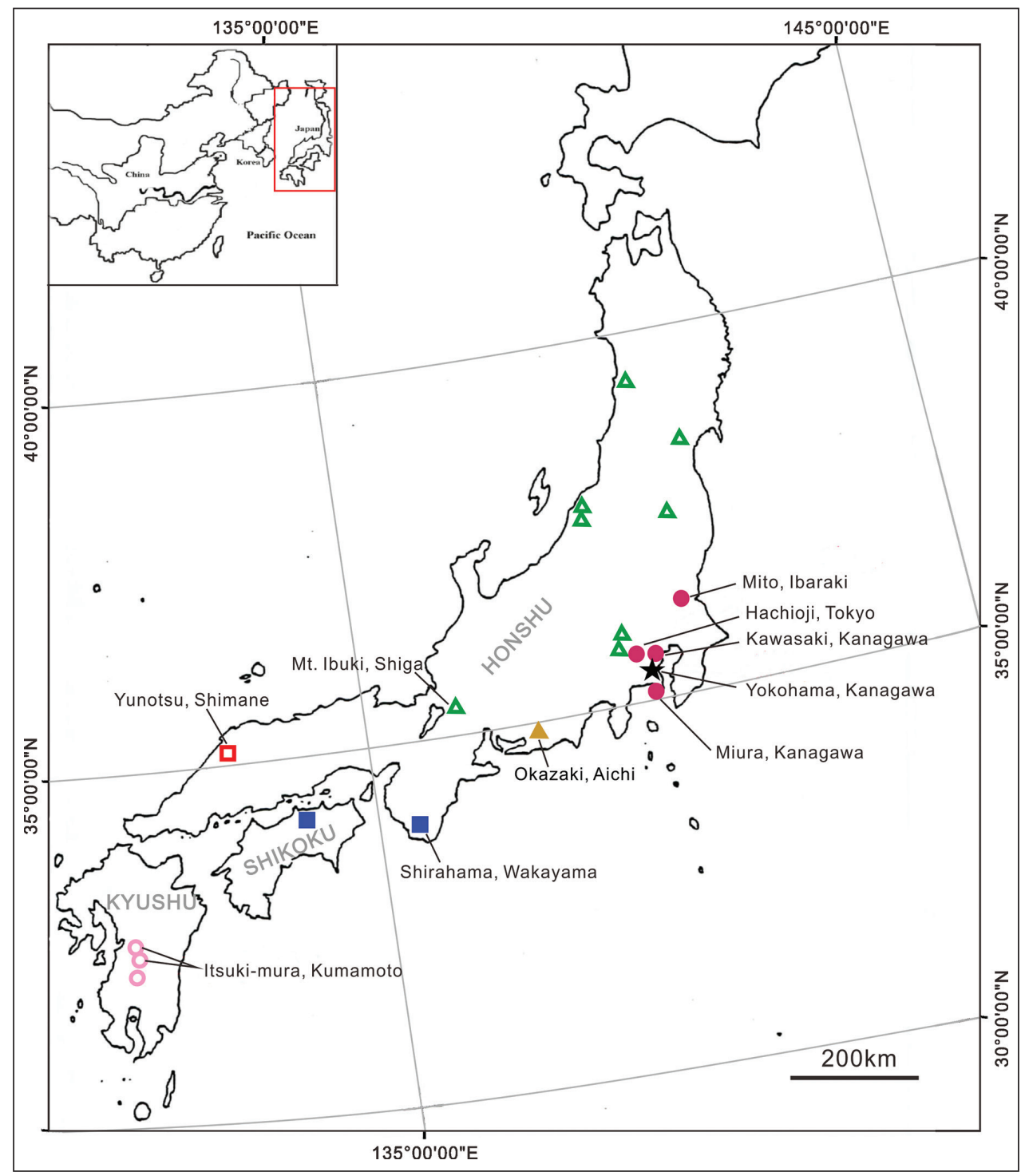

Figure 7. Collecting locations of Solenysa species from Japan.

S. mellotteei $\square$ S. macrodontasp. n.

$\Delta$ S. ogatai $\Delta$ S. partibilis $\bigcirc$ S. reflexilis - S. trunciformis sp. n. $\star$ type locality of S. mellotteei.

Akihisa Andoh; 1q (CNU-J29), Japan, Kyushu, Kumamoto Prefecture, Sagara, $32^{\circ} 8.67^{\prime} \mathrm{N}, 130^{\circ} 51.53^{\prime} \mathrm{E}$, alt. 590 m, 28 Apr. 2009, coll. Akihisa Andoh; 1 ㅇ (CNUJ30), Japan, Kyushu, Kumamoto Prefecture, Sagara, Nagae, $32^{\circ} 18.67^{\prime} \mathrm{N}, 130^{\circ} 51.53^{\prime} \mathrm{E}$, alt. 170 m, 22 Jul. 2006, coll. Akihisa Andoh.

Diagnosis. See the diagnosis for S. macrodonta sp. n.

Description. Somatic characters as in the genus description (see also Tu and Li 2006, Tu and Hormiga 2011), and genital characters as in the description by Tu et al. (2007).

Distribution. Japan (Kyushu, Fig. 7). 


\section{Solenysa trunciformis sp. $\mathbf{n}$.}

http://zoobank.org/AD5A06F1-6832-4FFB-B5E0-652F483A491A

Figs 1A-D, 3B, 5E-F

Solenysa melloteei: Tu and Li 2006: 91, figs 21-30; Tu and Hormiga 2011: 499, fig. 8A-I (misidentification).

Types. Male holotype (CNU-J26), Japan, Honshu, Wakayama Prefecture, Shirahama,

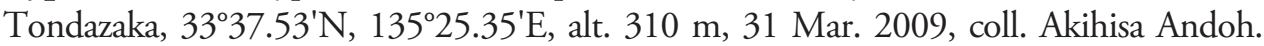

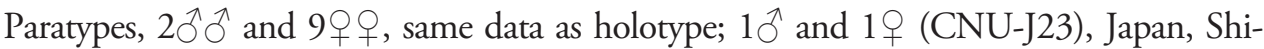
koku, Kagawa Prefecture, Takamatsu, Nishi-ueda, $34^{\circ} 13.22^{\prime} \mathrm{N}, 134^{\circ} 04.62^{\prime}$ E, alt. $130 \mathrm{~m}$,

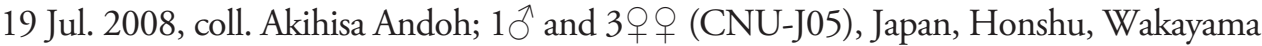
Prefecture, Susami-cho, Esuzaki, 3330'N, 135³4.20'E, 24 Aug. 1981, coll. Yoshito Ishii.

Diagnosis. The male palpal characters of $S$. trunciformis sp. n. (Figs 1C, 3B, 6F) are similar to those of $S$. macrodonta sp. n. and S. refrexilis; to distinguish them see the diagnosis for $S$. macrodonta sp. $\mathrm{n}$. The female is distinguished by the apple-shaped epigyne with a rectangular epigynal collar (Fig. 5F).

Description. Somatic characters as in the genus description and genital characters as in the descriptions for $S$. mellotteei by Tu and Li (2006) and Tu and Hormiga (2011).

Etymology. The species name comes from the Latin 'trunciformis' in reference to truncate apex of anterior protrusion in front of median terminal apophysis (Fig. 1C).

Distribution. Japan (Honshu, Shikoku, Fig. 7).

\section{Key to Solenysa species from the islands of Japan}

1 2

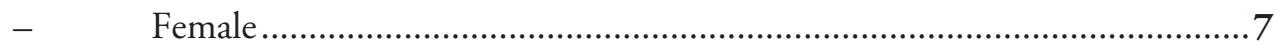

$2 \quad \mathrm{LC}_{2}$ with a forked apex, $\mathrm{LC}_{3}$ unbranched (Fig. 3A) ……............................ 3

- $\quad \mathrm{LC}_{2}$ with a sharp apex, $\mathrm{LC}_{3}$ includes two parts (Fig. 3C) 5

3 MTA with serrated margin (Fig. 3A)

S. macrodonta sp. $\mathrm{n}$.

MTA with smooth margin and two anterior protrusions (Fig. 3B) 4

$4 \quad$ First protrusion truncate (Fig. 3B) S. trunciformis sp. $\mathrm{n}$.

First protrusion pointed (Tu et al. 2007, fig. 1D) S. reflexilis Anterior part of $\mathrm{LC}_{3}$ flag-shaped (Fig. 2B) S. mellotteei Anterior part of $\mathrm{LC}_{3}$ spike-shaped (Fig. 3C-D) 6 Posterior part of $\mathrm{LC}_{3} \mathrm{~S}$-curved (Fig. 3C) S. ogatai Posterior part of $\mathrm{LC}_{3} \mathrm{~L}$-curved (Fig. 3D) S. partibilis

Dorsal plate almost as wide as long (Fig. 4B) .8

- $\quad$ Dorsal plate wider than long (Fig. 5B) . .9 Epigynal collar inversed triangular (Fig. 4A) S. mellotteei

- $\quad$ Epigynal collar rectangular (Fig. 5F) S. trunciformis sp. $\mathbf{n}$. 
- $\quad$ Posterior margin of epigyne straight (Fig. 4E) .............................. S. reflexilis $10 \quad$ Maximum width at anterior part (Fig. 5A) ...........................................11

- $\quad$ Maximum width in middle (Fig. 4C) ...........................S. macrodonta sp. n. 11 Epigynal collar more than four times wider than long (Fig. 5B)......S. ogatai - $\quad$ Epigynal collar less twice wider than long (Tu and Hormiga 2011: fig. 11I) .... S. partibilis

\section{Acknowledgements}

We thank Gustavo Hormiga, Yuri M. Marusik and Cor Vink for their comments on an earlier version of this paper. We also thank Akihisa Andoh for kindly providing Solenysa material collected from Japan. This study was supported by National Natural Sciences Foundation of China (NSFC-30670244, NSFC-30970314, NSFC-30911120070) and by the Program for Changiiang Scholars and Innovative Research Team in University (IRT-13081).

\section{References}

Álvarez-Padilla F, Hormiga G (2008) A protocol for digesting internal soft tissues and mounting spiders for scanning electron microscopy. Journal of Arachnology 35: 538-542. doi: 10.1636/Sh06-55.1

Arnedo MA, Hormiga G, Scharff N (2009) Higher-level phylogenetics of linyphiid spiders (Araneae, Linyphiidae) based on morphological and molecular evidence. Cladistics 25: 1-32. doi: 10.1111/j.1096-0031.2009.00249.x

Chikuni Y (1989) Pictorial Encyclopedia of Spiders of Japan. Kaisei-sha, Tokyo, 308 pp.

Coddington JA (1983) A temporary slide mount allowing precise manipulation of small structures. Verhandlungen des Naturwissenschaftlichen Vereins in Hamburg 26: 291-292.

Gao J, Zhu C, Sha Y (1993) Two new species of the genus Solenysa from China (Araneae: Linyphiidae: Erigoninae). Acta Arachnologica Sinica 2: 65-68.

Grandjean F (1949) Observation et conservation des très petits arthropodes. Bulletin du Muséum National d'Histoire naturelle 21: 363-370.

Holm Å (1979) A taxonomic study of European and East African species of the genera Pelecopsis and Trichopterna (Araneae, Linyphiidae), with descriptions of a new genus and two new species of Pelecopsis from Kenya. Zoologica Scripta 8: 255-278. doi: 10.1111/j.14636409.1979.tb00638.x

Irie T, Saito H (1987) A list of linyphiid spiders in Kumamoto Prefecture. Heptathela (Spider Study Group of Kyushu) 3(2): 14-30.

Lee YB, Yoo JS, Lee DJ, Kim JP (2004) Ground dwelling spiders. Korean Arachnology 20: 97-115.

Li S, Song D (1992) On two new species of soil linyphiid spiders from China (Araneae: Linyphiidae: Erigoninae). Acta Arachnologica Sinica 1: 6-9. 
Oi R (1960) Linyphiid spiders of Japan. Journal of the Institute of Polytechnics, Osaka City University, Series D 11: 137-244, pls. I-XXV.

Ono H (1987) Discovery of Japanese spiders. In: Yajima M (Ed.) The Encyclopaedia of Animals. Heibonsha, Tokyo, 160-161.

Ono H (2011) Notes on Japanese Spiders of the Genera Paikiniana and Solenysa (Araneae, Linyphiidae). Bulletin of the National Museum of Natural Science, 37: 121-129.

Ono H, Matsuda M, Saito H (2009) Linyphiidae. In: Ono H (Ed.) The Spiders of Japan, with Keys to the Families and Genera and Illustration of the Species. Tokai University Press, Kanagawa, 253-342.

Saaristo MI (2007) A new subfamily of linyphiid spiders based on a new genus created for the keyserlingi-group of the genus Lepthyphantes (Aranei: Linyphiidae). Arthropoda Selecta 16: $33-42$.

Seo BK (1996) A new species of genus Solenysa (Araneae: Linyphiidae) from Korea. Journal of Institute for Natural Sciences, Keimyung University 15: 157-159.

Simon E (1886a) Espèces et genres nouveaux de la famille des Thomisidae. Actes de la Société linnéenne de Bordeaux 40: 167-187.

Simon E (1886b) Descriptions de quelque espèces nouvelles de la famille des Agelenidae. Annales de la Société entomologique de Belgique Comptes Rendus 30: 57-61.

Simon E (1889) Etudes arachnologique. 21e Mémoire. XXXIII. Descriptions de quelque espèces recueillies au Japon, par A. Mellotée. Annales de la Société entomologique de France 8: 248-252.

Simon E (1893) Descriptions de quelque Arachnides appartenant aux familles des Leptonetidae et Oonopidae. Annales de la Société entomologique de France 62 Bulletin: 247-248.

Simon E (1894) Histoire Naturelle des Araignées, seconde édition. Tome 1, Fascicule 3. Libraire encyclopédique de Roret, Paris, 489-760.

Simon E (1895) Histoire Naturelle des Araignées, seconde édition. Tome 1, Fascicule 4. Libraire encyclopédique de Roret, Paris, 761-1084.

Sun N, Marusik YM, Tu L (2014) Acanoides gen. n., a new spider genus from China with a note on the taxonomic status of Acanthoneta Eskov \& Marusik, 1992 (Araneae, Linyphiidae, Micronetinae). ZooKeys 375: 75-99. doi: 10.3897/zookeys.375.6116

Takahashi M (2000) Foreign specialists employed by the Meiji Government of Japan and the Japanese spiders. Printed synopsis distributed at the Annual Meeting (2000) of the Tokyo Spider Study Group, 10 pp.

Tanasevitch AV (1996) Reassessment of the spider genus Wubanoides Eskov, 1986 (Arachnida: Araneae: Linyphiidae). Reichenbachia 31: 123-129.

Tu L, Li S (2006) A review of the linyphiid spider genus Solenysa (Araneae, Linyphiidae). Journal of Arachnology 34: 87-97. doi: 10.1636/H03-26.1

Tu L, Ono H, Li S (2007) Two new species closely related to Solenysa melloteei Simon, 1894 (Araneae: Linyphiidae) from Japan. Zootaxa 1426: 57-62.

Tu L, Hormiga G (2011) Phylogenetic analysis and revision of the linyphiid spider genus Solenysa (Araneae: Linyphiidae: Erigoninae). Zoological Journal of the Linnean Society 161: 484-530. doi: 10.1111/j.1096-3642.2010.00640.x

Yaginuma T (1986) Spiders of Japan in Color, New Edition. Hoikusha, Osaka, xxiv+305 pp., pls. 1-64. 